\title{
Evaluation of Comparative Effect of Feed Additive of Allium Sativum and Zingeber Officinale on Bird Growth and Histomorphometric Characteristics of Small Intestine in Broilers
}

Original Article

\section{-Author(s)}

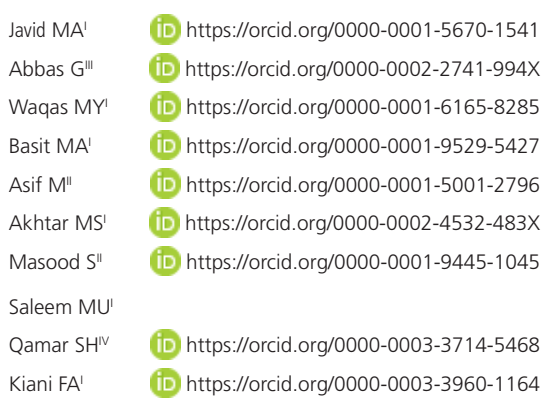

Faculty of Veterinary Sciences, Bahauddin Zakariya University, Multan, Pakistan.

University of Veterinary and Animal Sciences, Lahore, Pakistan.

III Riphah College of Veterinary Sciences, Lahore, Pakistan.

Animal Nutrition Institute, Sichuan Agricultural University Chengdu, China.

\section{Mail Address}

Corresponding author e-mail address Ghulam Abbas

Department of Animal Production, Riphah College of Veterinary Sciences, Lahore, 00000000, Pakistan.

Email: ghulamabbas_hashmi@yahoo. com

\section{- Keywords}

Ginger, Garlic, Bird performance, Histomorphometry, Small intestine.

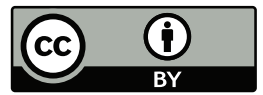

Submitted: 13/January/2019 Approved: 25/February/2019

\section{ABSTRACT}

The present study was conducted to evaluate the effects of supplementation of garlic, ginger in the diets of broiler chickens and assessment in terms of feed intake, growth performance and economics of feeding. The results showed that groups supplemented with $0.5 \%$ garlic powder and $0.5 \%$ ginger powder has shown significant effects on body weight as compared to the control group at day 28. Groups supplemented with $0.5 \%$ garlic powder and $0.5 \%$ ginger powder show significant increase in body weight than the groups supplemented with $0.25 \%$ garlic powder and $0.25 \%$ ginger powder. Between different supplemented groups, villus length and width of duodenum and jejunum of birds served with $0.5 \%$ garlic powder and $0.5 \%$ ginger powder is significantly higher than the villus length and width of birds supplemented with $0.25 \%$ garlic and $0.25 \%$ ginger powder. Between different supplemented groups, villus length of ileum of the group supplemented with $0.5 \%$ garlic powder is significantly $(p<0.05)$ lower than the villus length of the groups supplemented with $0.25 \%$ garlic powder and $0.25 \%$ ginger powder.

\section{INTRODUCTION}

Feed additives are a group of nutrient compounds which helps in improving the efficiency of feed utilization and making it cost effective. Feed is the major component of total costs of poultry venture as $80 \%$ of the total expenditure is on procurement of feed (Asghar et al., 2000). Allium sativum is commonly known as garlic, belongs to the family Amaryllidaceae and subfamily Allioideae. Its other common names are garlic, shallot, leek chive and rakkyo. It grows prominently in sub-continent. It is a well-known spice. It is also used as traditional medicine for therapeutic response and prevention of various health problems (Adimoradi et al. 2006). Furthermore, it has antimicrobial, antihypertensive and antioxidant properties (Konjufca et al. 1997; Sivam, 2001). Hypocholesterolemic effect was observed in chickens due to the use of garlic powder (Konjufca et al. 1997; Qureshi et al. 1983). Tollba \& Hassan (2003) stated that garlic is a well-known natural supplement which has decreased mortality rate, brought positive changes in feed conversion ratio and improved the growth of broiler chicken. The exact mode of action is hard to understand. The moderate dose of the garlic can increase the villus height linearly in duodenum, jejunum and ileum. However garlic supplementation at higher doses 0.5 to $2.0 \%$ increases $(p<0.05)$ the crypt depth, which resulted in lower crypt to villi ratio in duodenum and higher in jejunum and ileum (Konjufca et al. 1997). One of the purposes of this study is to investigate its effects on intestinal morphology as it has the ability to change the intestinal absorption.

Zingeber officinale (Ginger) is another spice. It belongs to the family Zingiberceae. Other notable members of this plant family are 
Javid MA, Abbas G, Waqas MY,

Basit MA, Asif M, Akhtar MS, Masood S,

Saleem MU, Qamar SH, Kiani FA
Evaluation of Comparative Effect of Feed Additive of Allium Sativum and Zingeber Officinale on Bird Growth and Histomorphometric Characteristics of Small Intestine in Broilers turmeric, cardamom, and galangal. It is well known for its medicinal and flavouring properties (Onyenekwe \& Hashimoto, 1999). For centuries it has been used as an edible plant and it remained as an important constituent of Tib, Unani and Chinese medicine for the cure of diabetes, asthma, stroke, constipation, gingivitis, nervous diseases and catarrah (Tapsell et al. 2006, Wang and Wang, 2005, Awang, 1992). Nine compounds are found in ginger which may bind to serotonin receptors and may influence gastrointestinal function. Some in-vitro studies showed that ginger extract can have the ability to control the quantity of free radicals and the peroxidation of lipids (Al.amin et al. 2006)

Ginger is also used as a treatment of different diseases i.e. dyspepsia, flatulence, diarrhea and colic (Borrelli et al., 2004) and works as an appetite stimulant (White, 2007). Moreover, it has an anti-inflamatory (Grzanna et al.; 2005) as well as cancer prevention properties (Shukla \& Singh; 2007). Herbal extracts, organic acid, Prebiotics, enzymes and probiotics are widely used in feed of poultry as an alternative of sub-therapeutic antibiotics (Yahkeshi et al. 2011). Its mode of action includes the variation in gut histomorphometric parameters (Markovic et al. 2009), intestinal and growth performance (Patterson \& Burkholder 2003), immune system and antibacterial activity (Thenmozhi et al. 2012, Schley \& Field 2002). Reduction in gut pathogenic bacteria causes reduction of competition for microbial nutrients, increase availability of nutrients and decrease in size of muscularis mucosa resulting in increased absorption capacity (Yahkeshi et al. 2011). The absorptive surface area is increased due to the increase in width and length of the intestinal villi. Enterocytes undergo proliferation in the intestinal crypt and decreased crypt height can therefore be correlated with the increase in growth rate in broilers (Markovic et al. 2009). It was hypothesized that the use of dietary Allium sativum and Zingeber officinale in broilers will induce structural changes in favor of higher body functions in major body organs. The aim of the present research is to evaluate the comparative efficacy of Allium sativum and Zingeber officinale supplementation on bird performance and histomorphometry of small intestine in broilers.

\section{MATERIALS AND METHODS}

The present research trial was conducted at the experimental Animal House, Department of Biosciences, Faculty of Veterinary Sciences, Bahauddin
Zakariya University Multan for a period of 42 days (6 weeks). Samples were processed in the Histology lab.80 day-old chicks (hybrid) were purchased from Rising Poultry and were randomly divided into five groups with 04 replicates in each group comprising of 04 birds in each replicate. The control group (A) was fed with corn based basal diet while Group B was given basal diet $+0.25 \%$ Garlic powder, Group C was given basal diet $+0.50 \%$ Garlic Powder, Group D was given basal diet $+0.25 \%$ Ginger Powder and Group E was given basal diet $+0.50 \%$ Ginger Powder. The young chicks were raised in environmental controlled conditions and up to 42 days, water and feed were provided ad libitum. Infectious bursal disease and Newcastle Disease vaccines were given to the chicks as stated by (Giambrone \& Clay, 1986).

\section{Sampling and Processing}

On day 42, 8 birds were selected randomly from each group and then weighted for FCR. The birds were conventionally slaughtered and collection of intestinal samples was done. Furthermore, whole intestinal tract was removed. Whereas, lleo-cecal junction served as the landmark for small intestine. Samples from the duodenum, the jejunum as well as the ileum were taken with length of five centimeter each, respectively, as stated by Murakami et al. (2007). The samples were washed using normal saline and preserved in $10 \%$ buffer formalin solution. Tissue samples were dehydrated, cleared, impregnated and embedded in paraffin wax. $4 \mu \mathrm{m}$ thin sections were obtained with the help of microtome. Prior to mounting on slides, sections were cleared of wrinkles by floating on 55- $60^{\circ} \mathrm{C}$ warm water (Bancroft et al. 2008). Staining of intestinal samples was done by using eosin and haematoxylin (Bancroft et al. 2008). The slides were observed under light compound microscope. ProgRes ${ }^{\circledR}$ (CapturePro - Jenoptik AG) software was used to perform histomorphometry.

\section{Gut Histomorphometry}

In gastrointestinal morphometric variables, villus length and width were measured. One section per slide was taken from the tissue. On the basis of intact lamina propria five villi were selected for length and width of villi (Ashraf 2011). Laterly, average of fifteen values was calculated. The measurements for villus width from the midpoint and for villus length, from the top of the villus to the lamina propria were taken. Depth of invagination between the adjacent villi was measured for crypt depth (Awad et al., 2009). 
Javid MA, Abbas G, Waqas MY,

Basit MA, Asif M, Akhtar MS, Masood S,

Saleem MU, Qamar SH, Kiani FA
Evaluation of Comparative Effect of Feed Additive of Allium Sativum and Zingeber Officinale on Bird Growth and Histomorphometric Characteristics of Small Intestine in Broilers

\section{Statistical Analysis}

Data was analyzed with the statistical package for social science (SPSS) version 22 (Chicago IL, USA). Data was presented as mean \pm S.D. The group differences were compared by Duncan's Multiple Range Test (Panneerselvan 2004). Difference was considered significant at $p<0.05$.

\section{RESULTS}

In the present study, body weight of the birds at different days is showed in table 01. All the supplemented groups showed significant $(p<0.05)$ body weight compared to the body weight of the control group at day 14. Between different supplemented groups, Group-C and Group-E showed significant $(p<0.05)$ body weight compared to the body weight of group-B, body weight of Group-C is also significantly higher $(p<0.05)$ than the body weight of group-D at day 14. Groups supplemented with $0.5 \%$ garlic powder and $0.5 \%$ Ginger powder has shown significant increased $(p<0.05)$ effect on body weight as compared to the control group at day 28. Between different supplemented groups, groups supplemented with $0.5 \%$ garlic powder and $0.5 \%$ ginger powder show significant $(p<0.05)$ increase body weight compared to the groups supplemented with $0.25 \%$ garlic powder. Furthermore, group supplemented with $0.5 \%$ garlic powder show significantly higher body weight compared to the body weight of the group supplemented with $0.25 \%$ ginger powder. At day 42, birds served with supplemented feed expressed significant response $(p<0.05)$ to body weight compared to the body weight of the control group. Between different supplemented groups, body weight of group supplemented with $0.5 \%$ garlic powder showed significant result $(p<0.05)$ compared to the body weight of the groups supplemented with $0.25 \%$ Garlic powder and $0.25 \%$ ginger powder.

Gut histomorphometric measurements of villus width and villus length for duodenum, jejunum \&ilium are showed in table 2. Duodenal villus length and width of all supplemented groups are more significant $(p<0.05)$ than the villus length and width of group A (controlled group). Between different supplemented groups, villus length and width of duodenum of birds served with $0.5 \%$ garlic powder and $0.5 \%$ ginger powder is significantly higher $(p<0.05)$ than the villus length and width of the birds supplemented with $0.25 \%$ garlic and $0.25 \%$ ginger powder. The birds of the group served with $0.5 \%$ garlic powder showed higher $(p<0.05)$ values of villus length and width of duodenum than the birds served with $0.5 \%$ ginger powder. Duodenal crypt depth of all supplemented groups is significantly higher $(p<0.05)$ than the controlled group. Between different supplemented groups, the crypt depth of the groups supplemented with $0.5 \%$ garlic powder and $0.5 \%$ ginger powder is significantly more $(p<0.05)$ than the crypt depth of the groups supplemented with $0.25 \%$ garlic powder and $0.25 \%$ ginger powder.

Villus length of the jejunum of the birds of all supplemented groups is found more significant $(p<0.05)$ than the villus length of the control group. Between different supplemented groups, villus length of the jejunum of the birds served with $0.5 \%$ garlic powder and $0.5 \%$ ginger powder is more significant $(p<0.05)$ than the villus length of the birds fed $0.25 \%$ garlic powder and $0.25 \%$ ginger powder. Furthermore, jejunal villus length of the group supplemented with $0.5 \%$ garlic powder is significantly $(p<0.05)$ higher than the group supplemented with $0.5 \%$ ginger powder. Villus width of the jejunum of the birds of all supplemented groups is significantly lower $(p<0.05)$ than the villus width of the birds of the control group. Between different supplemented groups, the jejunal villus width of the group supplemented with $0.5 \%$ garlic powder is significantly $(p<0.05)$ decreased compared to the villus width of the groups supplemented with $0.25 \%$ garlic powder and $0.25 \%$ ginger powder. The jejunal crypt depth of all supplemented groups is significantly higher $(p<0.05)$ than the controlled group. Between different supplemented groups, the crypt depth of the groups supplemented with $0.25 \%$ garlic powder and $0.25 \%$ ginger powder is significantly lower $(p<0.05)$ than the crypt depth of the groups supplemented with

Table 01 - Weight of birds at day 01 to 42

\begin{tabular}{|c|c|c|c|c|c|}
\hline Weight (gm) & $\begin{array}{l}\text { Group-A } \\
\text { Controlled }\end{array}$ & $\begin{array}{c}\text { Group-B } \\
0.25 \% \text { Garlic }\end{array}$ & $\begin{array}{c}\text { Group-C } \\
0.50 \% \text { Garlic }\end{array}$ & $\begin{array}{c}\text { Group-D } \\
0.25 \% \text { Ginger }\end{array}$ & $\begin{array}{c}\text { Group-E } \\
0.50 \% \text { Ginger }\end{array}$ \\
\hline Weight at Day 01 & $44.50^{a} \pm 0.57$ & $45.13^{a} \pm 0.35$ & $44.13^{a} \pm 0.44$ & $43.63^{a} \pm 0.60$ & $44.0^{a} \pm 0.46$ \\
\hline Weight at Day 14 & $320.63^{a} \pm 1.46$ & $326.38^{b} \pm 1.35$ & $333.88^{d} \pm 1.62$ & $329.25^{b c} \pm 1.40$ & $331.88^{\mathrm{cd}} \pm 1.76$ \\
\hline Weight at Day 28 & $1002.13^{a} \pm 4.35$ & $1031.50^{b} \pm 5.63$ & $1068.50^{d} \pm 5.54$ & $1042.88^{b c} \pm 2.12$ & $1052.63^{c} \pm 5.28$ \\
\hline Weight at Day 42 & $2016.88^{a} \pm 10.98$ & $2066.38^{b} \pm 13.53$ & $2139.50^{c} \pm 12.77$ & $2090.0^{b} \pm 9.21$ & $2107.63^{b c} \pm 26.90$ \\
\hline
\end{tabular}

Different superscripts show values in a row differed significantly. 
Javid MA, Abbas G, Waqas MY,

Basit MA, Asif M, Akhtar MS, Masood S,

Saleem MU, Qamar SH, Kiani FA
Evaluation of Comparative Effect of Feed Additive of Allium Sativum and Zingeber Officinale on Bird Growth and Histomorphometric Characteristics of Small Intestine in Broilers
$0.5 \%$ garlic powder and $0.5 \%$ ginger powder. The jejunal crypt depth of the group supplemented with $0.5 \%$ garlic powder is significantly higher $(p<0.05)$ than the crypt depth of the group supplemented with $0.5 \%$ ginger powder.

The villus length of the lleum of the birds of all supplemented groups is significantly $(p<0.05)$ higherthan the villus length of the controlled birds. Between different supplemented groups, the villus length of the ileum of the group supplemented with $0.5 \%$ garlic powder is significantly $(p<0.05)$ lower than the villus length of the groups supplemented with $0.25 \%$ garlic powder and $0.25 \%$ ginger powder. The villus width of the lleum of all supplemented groups is significantly $(p<0.05)$ less-than the villus width of the controlled birds. Between different supplemented groups, the villus width of the groups supplemented with $0.5 \%$ ginger powder and $0.5 \%$ garlic powder is significantly $(p<0.05)$ lower than the villus width of the groups supplemented with $0.25 \%$ ginger powder and $0.25 \%$ garlic powder. The crypt depth of the ileum of groups supplemented with $0.25 \%$ garlic, $0.5 \%$ garlic and $0.5 \%$ ginger powder is significantly higher $(p<0.05)$ than the controlled group. Between the different supplemented groups, the crypt depth of the group supplemented with $0.5 \%$ garlic powder is significantly higher $(p<0.05)$ than the groups supplemented with $0.25 \%$ garlic powder and $0.25 \%$ ginger powder.

\section{DISCUSSION}

Demir et al. (2003) and Lewis et al. (2003) stated that broilers fed with garlic supplementation showed increased body weight and feed conversation ratio. The birds served with the mixture of ginger and garlic haded increased final body weight as stated by Ademola et al. (2009). Similarly, (Onu 2010) stated that the birds served with ginger and garlic mixture (combination of $0.25 \%$ ) expressed increase in body weight as compared to the control group. In contrast, Omage et al. (2007) and Konjufca et al. (1997) stated that broiler birds fed with supplementations of ginger and garlic did not affect feed conversation ratio and body weight gain from the age of day 1 to 21 . Similarly, Qureshi et al. (1983) reported that the birds fed the basal diet with different products of garlic added at the level of $50 \mathrm{gm} / \mathrm{kg}$ did not affect the daily feed consumption and final body weight of the birds. The increase in body weight is observed due to healthy micro flora as well as gut environment produced by supplementation of ginger and garlic powder. The use of ginger and garlic in the present study gives a clear speculation about the direct involvement of these supplements on production traits.

Gupta \& Sandhu (1998) stated that the intestinal villus length increased due to cellular hyperplasia and hypertrophy when rats were offered garlic

Table 02 - Small Intestine Histomorphometric parameters.

\begin{tabular}{|c|c|c|c|c|c|}
\hline Parameters (um) & $\begin{array}{c}\text { Group-A } \\
\text { Controlled }\end{array}$ & $\begin{array}{c}\text { Group-B } \\
0.25 \% \text { Garlic }\end{array}$ & $\begin{array}{c}\text { Group-C } \\
0.50 \% \text { Garlic }\end{array}$ & $\begin{array}{c}\text { Group-D } \\
0.25 \% \text { Ginger }\end{array}$ & $\begin{array}{c}\text { Group-E } \\
0.50 \% \text { Ginger }\end{array}$ \\
\hline Duodenum Villus Length & $981.0^{a} \pm 13.69$ & $1295.63^{b} \pm 17.25$ & $1533.63^{d} \pm 21.44$ & $1338.75^{b} \pm 26.11$ & $1418.25^{c} \pm 26.91$ \\
\hline Duodenum Villus Width & $152.88^{a} \pm 4.25$ & $175.0^{b} \pm 2.90$ & $246.38^{d} \pm 6.02$ & $185.0^{b} \pm 5.39$ & $222.13^{c} \pm 7.05$ \\
\hline Duodenum Crypt Depth & $139.63^{\mathrm{a}} \pm 1.56$ & $145.63^{b} \pm 0.98$ & $152.75^{c} \pm 0.67$ & $144.0^{b} \pm 1.16$ & $149.88^{c} \pm 1.11$ \\
\hline Jejunum Villus Length & $886.25^{a} \pm 7.16$ & $998.88^{b} \pm 7.15$ & $1154.0^{d} \pm 23.52$ & $980.13^{b} \pm 16.55$ & $1076.13^{c} \pm 19.99$ \\
\hline Jejunum Villus Width & $165.0^{d} \pm 6.90$ & $134.0^{\mathrm{bc}} \pm 4.71$ & $113.50^{a} \pm 4.38$ & $145.0^{c} \pm 3.49$ & $126.0^{\mathrm{ab}} \pm 3.93$ \\
\hline Jejunum Crypt Depth & $107.63^{a} \pm 1.29$ & $115.13^{b} \pm 1.80$ & $138.88^{d} \pm 1.56$ & $113.75^{b} \pm 1.58$ & $132.13^{c} \pm 1.23$ \\
\hline Ileum Villus Length & $532.13^{\mathrm{a}} \pm 4.70$ & $569.63^{c d} \pm 13.14$ & $548.50^{b} \pm 3.54$ & $577.75^{d} \pm 5.56$ & $559.0^{\mathrm{bc}} \pm 3.59$ \\
\hline Ileum Villus Width & $186.0^{d} \pm 2.29$ & $155.0^{b} \pm 2.16$ & $143.0^{\mathrm{a}} \pm 1.95$ & $166.75^{c} \pm 1.77$ & $147.88^{a} \pm 1.39$ \\
\hline Ileum Crypt Depth & $105.88^{a} \pm 0.93$ & $110.88^{b c} \pm 1.33$ & $115.50^{d} \pm 1.74$ & $108.88^{\mathrm{ab}} \pm 1.38$ & $114.50^{\mathrm{cd}} \pm 0.98$ \\
\hline
\end{tabular}

Values showing different superscripts in a row differed significantly.

agglutinin diet. Furthermore, it was also observed that the thinning and lengthening of the jejunal villus, sloughing off jejunal mucosa and the increased number of goblet cells were caused in rats due to garlic agglutinin supplements in the diet. On the other hand, it has been studied that birds fed barley-based diet showed reduction in the villus width, length and surface area (Moharrery \& Mohammadpour, 2005). They also noticed the gradual decrease in villi length and surface area from the duodenum to the ileum.
The inhibition of the volatile fatty acids as well as microbial production of the polyamines accounted for the thinning of the gastrointestinal wall which resulted inenhanced activity and rate of enterocyte. Ultimately the increase in net energy accounted for sustaining the luminal tissue due to more productive purposes such as muscle accretion (Bedford, 2000). Longer and thinner villi, especially in the duodenal section, noticed due to ginger and garlic supplementation were reported in the present study. 
Javid MA, Abbas G, Waqas MY,

Basit MA, Asif M, Akhtar MS, Masood S,

Saleem MU, Qamar SH, Kiani FA
Evaluation of Comparative Effect of Feed Additive

of Allium Sativum and Zingeber Officinale on Bird Growth and Histomorphometric Characteristics of Small Intestine in Broilers
The findings of the present study clearly demonstrated that garlic and ginger supplementations improve the bird performance and histomorphometric parameters of small intestine in chickens.

\section{ACKNOWLEDGEMENTS}

The research grant was provided by Research and External Linkages, Bahauddin Zakariya University, Multan. The authors are thankful to Research and External Linkages, Bahauddin Zakariya University, Multan for providing facilities and funds for research.

\section{REFERENCES}

Ademola SG, Farinu G, Babatunde GM. Serum lipid, growth and hematological parameters of broilers fed garlic, ginger and their mixtures. World Journal Agricultural Science 2009;5:99-104.

Adibmoradi M, Navidshad B, Seifdavati J, Royan M. Effect of dietary garlic meal on histological structure of small intestine in broiler chickens. Journal Poultry Science 2006;43:378-383.

Al-Amin ZM, Thomson M, Al-QattanKK, Peltonen-Shalaby R, Ali M. Antidiabetic and hypolipideamic properties of ginger (Zingiberofficinale) in streptozotocin-induced diabetic rats. British Journal Nutrition 2006;96: 660-666.

Asghar A, Farooq M, Mian MA, Khurshid A. Economics of broiler production of Mardandivision. Journal of Rural Development 2000;32(3):56-65.

Ashraf S. Histological modulations in goblet cells and intraepithelial lymphocytes dynamics in broilers under selected environmental and dietary conditions [thesis]. Lahore (PK): Anatomy \& University of Veterinary and Animal Sciences; 2011.

Awad WA, Ghareeb K, Abdel-Raheem S, Bohm J. Effects of dietary inclusion of probiotic and synbiotic on growth performance, organ weights and intestinal histomorphology of broiler chickens. Poultry Science 2009;88: 49-55.

Awang DVC. Ginger. Canadian Pharmacits Journal 1992;125: 309-311.

Bancroft JD, Gamble M, Bancroft OD. Theory and practice of histological techniques. $6^{\text {th }}$ ed. New York: Elsevier Health Sciences; 2008. 725 p.

Bedford M. Removal of antibiotic growth promoters from poultry diets: implications and strategies to minimizesubsequent problems. World Poultry Science Journal 2000;56:236-243.

Borrelli F, Capasso R, Pinto A, Izzo AA. Inhibitory effect of ginger (Zingiberofficinale) on rat ileal motility in vitro. Life Science 2004;74(23):2889-96.

Demir E, Sarica S, Ozcan MA, Suicmez M. The use of natural feed additives as alternatives for an antibiotic growth promoter in broiler diet. British Poultry Science 2003;44:S44-S45.

Giambron JJ, Clay RP. Vaccination of day-old broiler chicks against Newcastle disease and infection bursal disease using live and/or inactivated vaccines. Avian Diseases 1986:30:557-561.

Grzanna R, Lindmark L, Frondoza CG. Ginger-an herbal medicinal product with broad anti-inflammatory actions. Journal of Medicine Food 2005;8(2):125-32.

Gupta A, Sandhu RS. Effect of garlic agglutinin and garlic extracts on the rat jejunum. Nutrition Research1998:8:841-850
Konjufca VH, Pesti GM, Bakalli RI. Modulation of cholesterol levels in broiler meat by dietary garlic and copper. Poultry Science 1997;76:1264-1271.

Lewis MR, Rose SP, Mackenzie AM, Tucker LA. Effects of dietary inclusion of plant extracts on the growth performance of male broiler chickens. British Poultry Science 2003;44:S43-S44.

Markovic R, Sefer D, Krstic M, Petrujkic B. Effect of different growth promoters on broiler performance and gut morphology. Archivos de Medicina Veterinaria 2009;41:163-169.

Moharrery A, Mohammadpour AA. Effect of diets containing different quali qualities of barley on growth performance and serum amylase and intestinal villus morphology. International Journal Poultry Science 2005:4:549-556

Murakami AE, Sakamoto MI, Natali MRM, Souza LMG, Franco JRG. Supplementation of glutamine and vitamin $\mathrm{E}$ on the morphometry of the intestinal mucosa in broiler chickens. Poultry Science 2007;86:488495.

Omage JJ, Onimisi PA, Adegbite EK and Agunbiade MO. The effect of Ginger (Zingiber officinale Roscoe) waste meal on growth performance, carcass characteristics, serum lipid and serum cholesterol profiles of rabbit. Pakistan Journal of Nutrition 2007;6(4): 359-362.

Onu PN. Evaluation of two herbal spices as feed additives for finisher broilers. Biotechnology in Animal Husbandry 2010;26(5/6):383-392.

Onyenekwe PC, Hashimoto S. The composition of the essential oil of dried Nigerian ginger (Zingiber officinale Roscoe). European Food Research and Technology 1999;209(6):407-410.

Panneerselvan R. Research methodology. New Delhi: Prentice-Hall of India; 2004. p. $98-100$

Patterson JA, Burkholder KM. Application of prebiotics and probiotics in poultry production. Poultry Science 2003;82:627-631.

Qureshi AA, Abuirmeileh N, Din ZZ, Elson CE, Burger WC. Inhibition of cholesterol and fatty acid biosynthesis in liver enzymes and chicken hepatocytes by polar fractions of garlic. Lipids 1983;18:343-348.

Schley PD, Field CJ. The immune enhancing effects of dietary fibers and prebiotics. British Journl of Nutrition 2002;87:221-230.

Shukla $Y$, Singh $M$. Cancer preventive properties of ginger: $A$ brief review. Food Chemical Toxicology 2007;45(5):683-690.

Sivam GP. Protection against helicobacter pylori and other bacterial infections by garlic. Journal of Nutrition 2001;131:1106-1108.

Tapsell LC, Hemphill I, Cobiac L, Patch CS, Sullivan DR, Fenech M, et al. Health benefits of herbs and spices: the past, the present, the future. Medical Journal of Australia 2006;185:S4-S24

Thenmozhi R, Nithyanand P, Rathna J, Pandian SK. Antibiofilm activity of coral-associated bacteria against different clinical $M$ serotypes of Streptococcus pyogenes. FEMS Immunology and Medical Microbiology 2009:57:284-294.

Tollba AAH, Hassan MSH. Using some natural additives to improve physiological and productive performance of broiler chicks under high temperature conditions. 2. Black cumin (Nigella Sativa) or garlic (Allium Sativum). Poultry Science 2003;23:327-340.

Wang WH, Wang ZM. Studies of commonly used traditional medicineginger. Zhongguo Zhongyao Zazhi 2005;30:1569-1573.

White B. Ginger: aAn overview. American Family Physician 2007;75(11):1689-1691.

Yakhkeshi S, Rahimi S, GharibNaseri K. The effect of camparison of herbal extracts, antibiotics, probiotic and organic acid on serum lipids, immune response, GIT microbial population, intestinal morphology and performance of broilers. Journal of Medicial Plants 2011:10:37. 
Javid MA, Abbas G, Waqas MY,

Basit MA, Asif M, Akhtar MS, Masood S,

Saleem MU, Qamar SH, Kiani FA

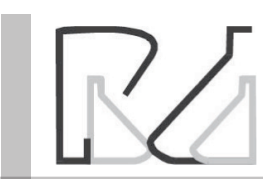

Evaluation of Comparative Effect of Feed Additive of Allium Sativum and Zingeber Officinale on Bird Growth and Histomorphometric Characteristics of Small Intestine in Broilers

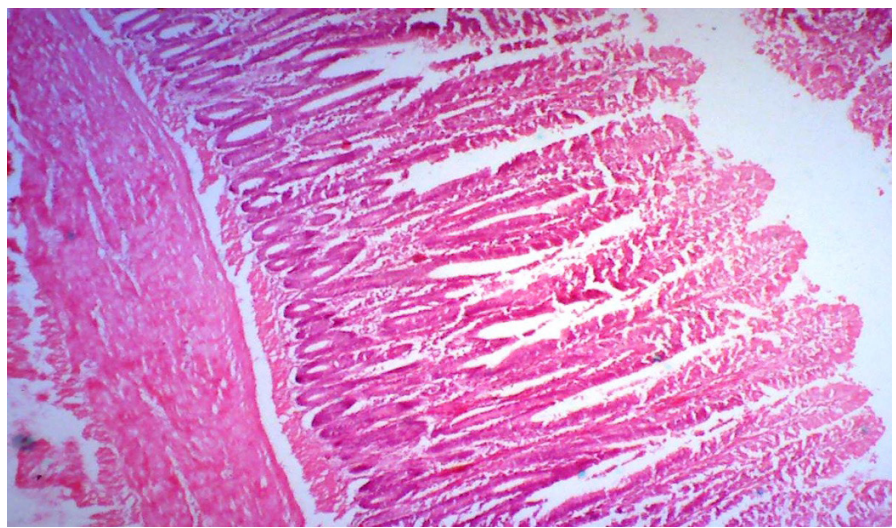

Figure 1 - Duodenum Villi of birds fed with $0.5 \%$ ginger powder.

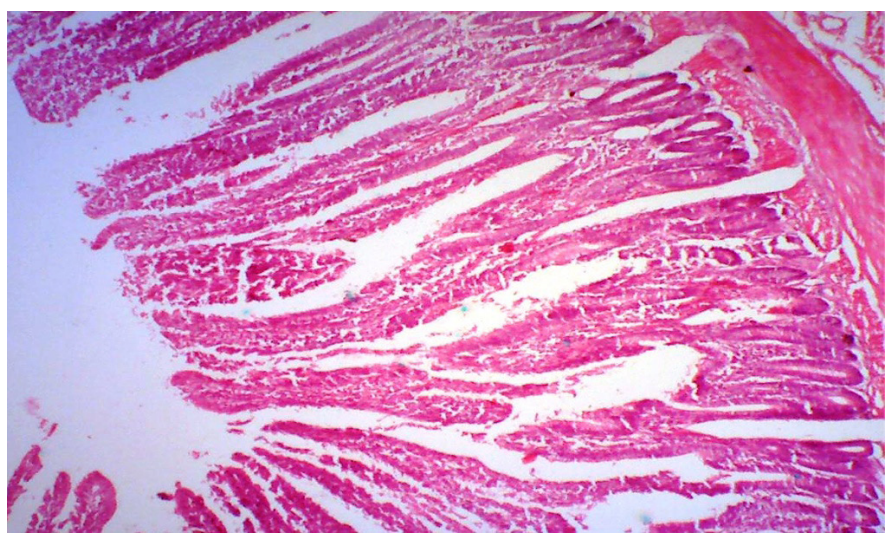

Figure 2 - Duodenum Villi of birds fed with $0.5 \%$ garlic powder.

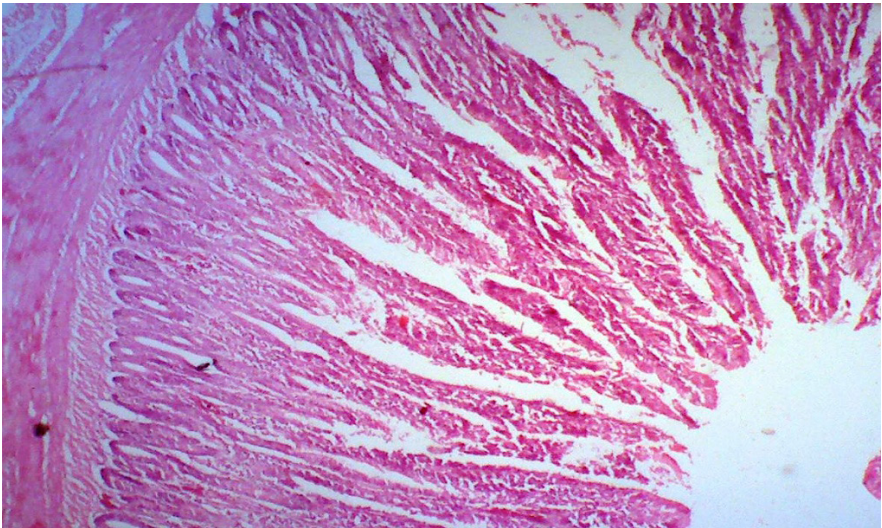

Figure 3 - Jejunum Villi of birds fed with $0.5 \%$ garlic powder.

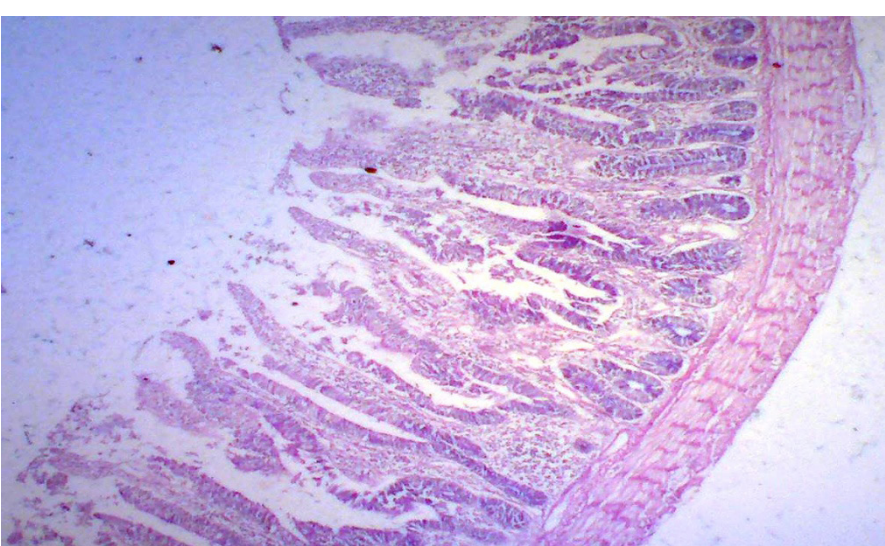

Figure 4 - llium Villi of birds fed with $0.25 \%$ ginger powder. 